\title{
Lumen
}

Selected Proceedings from the Canadian Society for Eighteenth-Century Studies

\section{Conjectural History vs. the Bible: Eighteenth-Century Scottish Historians and the Idea of History in the Encyclopaedia Britannica}

\section{Silvia Sebastiani}

Volume 21, 2002

URI : https://id.erudit.org/iderudit/1012276ar

DOI : https://doi.org/10.7202/1012276ar

Aller au sommaire du numéro

Éditeur(s)

Canadian Society for Eighteenth-Century Studies / Société canadienne d'étude du dix-huitième siècle

ISSN

1209-3696 (imprimé)

1927-8284 (numérique)

Découvrir la revue

Citer cet article

Sebastiani, S. (2002). Conjectural History vs. the Bible: Eighteenth-Century Scottish Historians and the Idea of History in the Encyclopaedia Britannica. Lumen, 21, 213-231. https://doi.org/10.7202/1012276ar

Copyright (c) Canadian Society for Eighteenth-Century Studies / Sociéte canadienne d'étude du dix-huitième siècle, 2002
Ce document est protégé par la loi sur le droit d'auteur. L'utilisation des services d'Érudit (y compris la reproduction) est assujettie à sa politique d'utilisation que vous pouvez consulter en ligne.

https://apropos.erudit.org/fr/usagers/politique-dutilisation/ 


\section{Conjectural History vs. the Bible: Eighteenth-Century Scottish Historians and the Idea of History in the Encyclopaedia Britannica}

The negative reaction to the French Revolution embodied in the volumes of the third edition of the Encyclopaedia Britannica ${ }^{1}$ published in the 1790 s

1 Abbreviations. EB1: Encyclopaedia Britannica, or a Dictionary of Arts and Sciences, Compiled upon a new Plan [...] by a Society of Gentlemen in Scotland, ed. W. Smellie, 3 vols (London, 1773); EB2: Encyclopaedia Britannica; or, a Dictionary of Arts, Sciences, \&c. on a Plan Entirely New [...]. 2nd Edition; Greatly Improved and Enlarged, ed. J. Tytler, 10 vols. (Edinburgh, 1778-83); EB3: Encyclopaedia Britannica; or a Dictionary of Arts, Sciences and Miscellaneous Literature [...]. The Third Edition, in Eighteen Volumes, Greatly Improved, ed. C. Macfarquhar (vols. 1-12) and G. Gleig (vols. 13-18), 18 vols. (Edinburgh, 1788-97). I presented a first version of this article at the conference of the Canadian Society for Eighteenth-Century Studies and the Eighteenth-Century Scottish Studies Society on 'Memory and Identity: Past and Present', Toronto, October 19-21, 2000. I would like to thank all the participants for their useful suggestions and comments, and in particular Richard Sher, Roger Emerson and Paul Wood. I also would like to thank John Robertson, John Brewer, Mario Caricchio and Lumen's anonymous reader for their precious help. EB1 began to appear in weekly sections between 1768 and 1771; once completed, it was published in Edinburgh in three volumes in quarto for subscribers by the printer Colin Macfarquhar (c.1745-1793) and the engraver Andrew Bell (1726-1809), and twice reprinted in London, in 1773 and 1775. Between 1777 and 1784 EB2, a second and enlarged edition, was published, once again in parts before the issue of a ten-volume edition in 1784. EB3 was issued in eighteen volumes between 1788 and 1797. On the publishing history of the Encyclopaedia Britannica, see T. Constable, Archibald Constable and His Literary Correspondents, 2 (Edinburgh, 1873), 311-317; L. M. Gooding, 'The Encyclopaedia Britannica: A Critical and Historical Study' (Master's thesis, Columbia University, 1929); P. Kruse, 'The Story of the Encyclopaedia Britannica, 1768-1943' (Ph.D. diss., University of Chicago, 1958); H. Kogan, The Great EB: The Story of the Encyclopaedia Britannica (Chicago, 1958); H. Einbinder, The Myth of the Britannica (London, 1964); R. L. Collison, Encyclopaedias: Their History throughout the Ages (New York, 1964); J. M. Wells, The Circle of Knowledge: Encyclopaedias Past and Present (Chicago, 1968); C. Fadiman, B. L. Felknor, R. McHenry, eds., The Treasury of the Encyclopaedia Britannica 
was sharpened by the belief, made explicit in the Supplement of 1801, that the French Encyclopédie had been the philosophical precursor of the massacres of the Terror. This was not the first time the Encyclopaedia Britannica had expressed fundamental objections to its famous French predecessor. In the preface to the first edition, Britannica's founding editor had criticized 'the folly of attempting to communicate science under the various technical terms arranged in an alphabetical order,' an attempt which he characterized as 'repugnant to the very idea of science. ${ }^{2}$ From the start, therefore, the Encyclopaedia Britannica rejected the strictly alphabetical arrangement of Chambers's Cyclopaedia (1728), a mode of organization followed by the writers of the Encyclopédie, which had begun as a project to translate Chambers's work. With the third edition, Britannica's editors launched a proper 'frontal assault' on the idea that a 'diagram or map' could reconstruct knowledge improperly scattered through the alphabet. A feature of the new method was the aspiration to achieve 'coherence at the level of disciplines,' which was pursued, as far as possible, by consulting the same expert for related articles and entries within the same field. ${ }^{3}$ But the third edition did more than intensify the application of a crucial founding principle. By abandoning the distinction between encyclopaedias, works of reference devoted to arts and sciences, and biographical and historical dictionaries, works of reference devoted to history, the third edition vastly extended its scope, virtually defining the modern conception of an encyclopaedia. ${ }^{4}$ Since history, in the age of the French Revolution, was a discipline

(New York, 1992). On the crucial role played by the proprietors Bell and Macfarquhar, see: F. A. Kafker, 'The Achievement of Andrew Bell and Colin Macfarquhar as the First Publishers of the Encyclopaedia Britannica,' British Journal for Eighteenth-Century Studies, 18.2 (1995), 139-152.

2 [W. Smellie], 'Preface,' EB1. On Britannica's reaction against alphabetical order, see G. Abbattista, 'La "folie de la raison par alphabet." Le origini settecentesche dell'Encyclopaedia Britannica 1768-1801,' in 'L'enciclopedismo in Italia nel XVIII secolo,' Studi Settecenteschi, 16 (1996), 435-476.

3 Gleig had a hand in a number of religious, philosophical and some important historical entries; David Doig wrote three important philological articles; 'Education', 'Religion' and 'Society' are recorded as Robert Heron's contributions. Large parts of the scientific section were supplied by James Tytler for the first twelve volumes, and after 1793 by John Robison. It is worth remembering that we know the specific contributions only in so far as Dr. Gleig knew them. See 'Preface,' EB3, 1: v-xvi.

4 R. Yeo, 'The Encyclopaedia Britannica and the Scottish Enlightenment,' Encyclopaedic Visions. Scientific Dictionaries and Enlightenment Culture (Cambridge, 2001), 170-192; see, in particular, 180. 
inevitably fraught with controversy, this revolutionary change to the scope of the Britannica exposes and illuminates the ideological environment in which the modern encyclopaedia took shape.

As is well known, the articles of the first two editions were almost entirely written or abridged by two individuals, William Smellie, a master printer, antiquarian and natural historian, ${ }^{5}$ and James Tytler, an eccentric balloonist, who trained as a ship's surgeon and whose political activities, deemed seditious, compelled his emigration to the United States in $1792 .{ }^{6}$ The third edition yet more fervently claimed philosophical unity, particularly after supervision passed from the publisher Colin Macfarquhar to the Episcopalian clergyman George Gleig of Stirling, later Bishop of Brechin. 'According to its 'Preface,' the Encyclopaedia Britannica was 'a dictionary, in which the several arts and sciences are digested into distinct treatises or systems, whilst the various detached

5 William Smellie (1740-1795), who was a member of several clubs in Edinburgh and the founder of the Newtonian Society, acquired a certain reputation in natural history, as the translator of Buffon's Histoire naturelle and the author of The Philosophy of Natural History (2 vols., Edinburgh, 1790-9). Contributor to the Scots Journal and the Weekly Journal, and co-editor, with Gilbert Stuart, of the Edinburgh Magazine and Review (Edinburgh, 1773-6), Smellie wrote the Literary and Characteristic Lives of John Gregory, Henry Home, Lord Kames, David Hume, and Adam Smith (Edinburgh, 1800), and the Account of the Institution and Progress of the Society of the Antiquarians of Scotland (Edinburgh, 1782-4). On his biography: R. Kerr, Memoirs of the Life, Writings and Correspondence of William Smellie (Edinburgh, 1811).

6 James Tytler (1747-1805) was described by George Gleig, in the 'Preface' to the third edition, as 'a man who, though his conduct has been marked by almost perpetual imprudence, possesses no common share of science and genius.' Before leaving for America, he continued to work as a contributor to the third edition. See Robert Meek, A Biographical Sketch of the Life of James Tytler, for a Considerable Time a Liberal Contributor to the Encyclopaedia Britannica (Edinburgh, 1805); J. Fergusson, Balloon Tytler (London, 1972).

7 Colin Macfarquhar, who was then sharing the ownership of the Britannica with Andrew Bell, edited the first 12 volumes of Britannica's third edition, until his death in 1793. George Gleig (1753-1840) took over the role, being already one of the principal advisors and contributors. Fellow of the Royal Society of Edinburgh and of the Society of Antiquaries of Scotland and contributor to the Monthly Review, the Gentleman's Magazine, and the Anti-Jacobin Review, Gleig co-edited with John Robison (1739-1805), secretary to the Royal Society of Edinburgh and professor of natural philosophy at Edinburgh, the Supplement to the Third Edition of the Encyclopaedia Britannica, published by Thomas Bonar in 1801, which made a number of significant revisions to the previous entries. For Gleig's career, see W. Walker, Life of the Right Reverend George Gleig, LL.D, F.S.S.A., Bishop of Brenchin, and Primus of the Scottish Episcopal Church (Edinburgh, 1878). 
parts of knowledge are explained in the order of the alphabet. ${ }^{8}$ The text compares classical knowledge with lively contemporary debate and creates an animated discussion in its pages, where 'arguments and objections have been displayed in their full force. ${ }^{9}$ The marginal subheadings, introduced from the second edition onwards, were aids for following the arguments and were the means by which a hierarchical organization could be imposed on the discussion.

Though Gleig claimed philosophical unity for the Britannica, it is questionable whether such coherence was really possible in such a collective work. There are contradictions in the Encyclopaedia Britannica, a fact acknowledged in the text itself, as well as in Gleig's private letters. In a note to the entry 'Slavery', for example, Gleig mentions that 'in the article Society, the reader will find another account of the origin of slavery, which we think likewise probable, though we have not transferred it to this place; as it would, in our opinion, be wrong to give to one writer what we know to belong to another.' Anyway, the editor took upon himself the task of reconciling the divergent accounts and indicating the right reading, asserting that 'between the two articles there is no contradiction, as barbarous wars were certainly one source of slavery. ${ }^{10}$ In a 1794 letter addressed to John Skinner, a central figure in the Episcopalian clergy, Gleig complained that he himself had failed to change the article 'Moral Philosophy' to the extent he thought necessary. ${ }^{11}$ Actually, wrote Gleig,

when the article Moral Philosophy was going through the press, I was not Editor of that great work. I was indeed often consulted by the Editor, and by him on this very subject. But when I proposed to give him a short system of Ethics, founded on religion and the hope of immortality, he expressed his dread of making his work unpopular, and would not listen to my proposal. ${ }^{12}$

8 G. Gleig, 'Preface,' EB3, 1: ix. In a similar way: [J. Tytler], 'Introduction', EB2, 1: iii-iv. See also W. E. Preece, 'The Organization of Knowledge and the Planning of Encyclopaedias: The Case of the Encyclopaedia Britannica,' Cahiers d'histoire mondiale, 9 (1966), 799-819.

9 G. Gleig, 'Preface,' EB3, 1: xii.

10 [G. Gleig], 'Slavery,' EB3, 3: 522-534, quotation on 522n, in contrast to [R. Heron] 'Society,' EB3, 17: 568-90.

11 Since the first edition, Britannica's article had in fact been a long abridgment from David Fordyce's Elements of Moral Philosophy (London, 1754). 'Moral Philosophy', EB1, 3: 270-309; EB2, 7: 1-38, but between pages 5192 and 5202; EB3, 12: 272-318.

12 See Theological Works of the late Rev. John Skinner, Episcopal Clergyman in Longsode, 
Nonetheless, as an advisor to Macfarquhar, Gleig managed to insert a 'History of the Science' as an introduction to the article, and made some small but pointed alterations in it by strategic interpolation and the addition of contrasting references. In this way, he was able to suggest 'safer guides in morals' that minimised the threat he found, for example, in the passage on the 'duty of resistance,' where the ecclesiastic Gleig is able to advance his cause with a quotation from an unexpected source, the 'infidel' David Hume. ${ }^{13}$ While it had not been economically profitable to Macfarquhar to play down the fashionable 'democratic' tendencies of the century in the 1780s, it became both right and profitable for Gleig to do so in the 1790s. So, despite inconsistencies in the earlier volumes of the third edition, coherence was constantly sought and pursued. This goal actually became feasible in the last six volumes, when Gleig himself officially took over the task of editing the Encyclopaedia Britannica. An especially coherent discourse emerged in moral philosophy, ethics, and religion, which were not only closest to Gleig's own personal interests, but also tightly linked to history, the latest significant interest of the Encyclopaedia Britannica. ${ }^{14}$ Thus, the Britannica acquired a clear ideological bias that was evangelical, Bible-centred, and based on the Mosaic account.

It has been commonly assumed that Britannica, the first modern encyclopedia, emerged as 'a direct product of the Scottish Enlightenment. ${ }^{15}$ Only very recently has it been suggested that there is no 'self-

Aberdeenshire, in two volumes. To which is prefixed, a Biographical Memoir of the Author, 2 vols. (Aberdeen, 1809), lxvi-lxvii.

13 'I am likewise answerable for the insertion of the extract from Hume, page 304; for, when I found the Editor determined to retain the vile paragraph about the Majesty of the People, and the Duty of Resistance, I thought it could not injure the reader, to lay before him on this subject, the sentiments of a man, of whom it cannot be said, that he was warped by religious prejudice, or that he had not opportunities of studying the principles of politics.' See: 'Moral Philosophy,' EB3, 12: 304. The passage quoted by Hume is from 'Of Passive Obedience,' in Essays Moral Political and Literary, ed. E. F. Miller (Indianapolis, 1985), 490. This passage is a clear statement of Gleig's political ideas.

14 The articles on history, as well as those on politics and biography, which were added in EB2, were a real novelty in an eighteenth-century encyclopaedia, because they pertained to the distinct genre of the historical dictionaries. It seems that Smellie resigned as an editor because he considered the enlargement to these new fields inconsistent with the aim of an encyclopedia of arts and science. See R. Kerr, Memoirs of the Life, Writings and Correspondence of William Smellie, 1: 363.

15 P. Rogers, 'Encyclopaedias,' in The Blackwell Companion to the Enlightenment, ed. J. W. Yolton et al. (Oxford, 1991), 144-5. This is a widely shared view. 
evident' link between the Encyclopaedia Britannica and the Scottish Enlightenment. This controversial reinterpretation is based on evidence that the first two editions remained at the margins of Scottish intellectual life, and that the methods and format of the work were viewed as suspect. ${ }^{16}$ What I suggest, using a brief survey of the entries related to history, religion, anthropology and society, is that the the third edition of Britannica systematically challenged not only French philosophy, but also the historiography of the Scottish Enlightenment. The editors considered the Scottish historiographical tradition as a part of the same dangerous spirit of the century, which developed the'materialism' of ancient philosophy in the new 'materialism' of the theory of the natural progress of society.

The main Scottish historians of the second half of the eighteenth century, from David Hume to John Millar, had definitely contributed to the development of modern historiography and human sciences. On the one hand, the narrative historians David Hume and William Robertson tried to find a way to balance the account of major developments in history with the need for positive evidence and reliable sources. On the other hand, the philosophical historians Adam Smith, Adam Ferguson, Lord Kames and John Millar applied the sociological speculations of Montesquieu to history, producing a conceptual framework to explain those major developments. Starting from Hume's theory of the 'uniformity of human nature,' the Scottish literati assumed that men in similar circumstances react in similar ways. So, in their histories, peoples passed through different stages of society, responding uniformly to the challenges of environment and social development. Departing fromthe savage state in which men were hunters living within simple tribes, societies next evolve into the barbarism of the shepherds, the stage in which property is introduced. The agricultural state follows, marked by the institutionalisation of government. Societies then evolve towards the complexity of eighteenth-century commercial society. Roughly speaking, this scheme is what Dugald Stewart called 'theoretical or conjectural

16 On the one hand, Richard Yeo critically discusses the relationship between the Encyclopaedia Britannica and the Scottish Enlightenment (Encyclopaedic Visions, 170-183); on the other, Frank Kafker underlines that the EB1 was almost unknown among the main Scottish literati, in his 'Introduction' to Encyclopaedia Britannica or, A Dictionary of Arts and Sciences. Preceded by The Prospectus for the First Edition, reprint of the first ed. (Routledge, 1997). The Monthly Review's negative comments on the first two editions of the Britannica show the sceptical attitudes of contemporaries towards the new method: Monthly Review, 50 (1774), 301-309; 75 (1786), 181-189. 
history, ${ }^{17}$ and what Ronald Meek, seeking Marx's sources, saw as a 'four stages theory. ${ }^{18}$ Scottish historians were well aware that growing complexity meant growing and multiplied challenges. Thus, starting from the same theoretical principles, the Scottish literati could account for the diversity of cultures in the more refined stages, such as Hume's 'national characters,' or even explain 'unnatural' historical paths, as does Smith's well-known description of the commercial development of Communal Italy. This flexible stadial scheme was the foundation of the major works of the Scottish Enlightenment in the 1770s: Ferguson's An Essay on the History of Civil Society (1767), Millar's The Origin of the Distinction of Ranks (1771), and Smith's An Enquiry into the Nature and Causes of the Wealth of Nations (1776), and a number of other enquiries by the Scottish historians. It also provided the framework for Sketches of the History of Man (1774), by Henry Home, Lord Kames, a judge of the Court of Session in Edinburgh, who was also the patron of almost all the Scottish literati. Kames, however, added an important and controversial gloss to the four stages theory: since not all peoples had emerged from savage and barbarian states, not all peoples, he asserted in 1774 , have the same 'human nature.' He therefore introduced the idea that different progenitors gave rise to different races of men, and inserted polygenesis as a necessary premise to the theory of progress through successive stages. ${ }^{19}$ Kames argued this

17 D. Stewart, Biographical Memoirs of Adam Smith, L.L.D., of William Robertson, D. D. and of Thomas Reid, D. D. Read before the Royal Society of Edinburgh, in Collected Works, 10 (Edinburgh, 1858), 33-34.

18 Ronald L. Meek, 'The Scottish Contribution to Marxist Sociology,' in Democracy and the Labour Movement, ed. by J. Saville (London, 1954), 84-102; Social Science and Ignoble Savage (Cambridge, 1976); 'Smith, Turgot, and the "Four Stages" Theory,' in Smith, Marx and after (London, 1980). Meek's Marxist point of view was indebted to the pioneer study of R. Pascal, 'Property and Society. The Scottish Historical School of the Eighteenth Century,' The Modern Quarterly, 1 (1938), 167-179.

19 H. Home, Lord Kames, Sketches on the History of Man (2 vols. 1774; 4 vols., Edinburgh, 1778). On Kames's anthropology, see R. Wokler, 'Apes and Races in the Scottish Enlightenment: Monboddo and Kames on the Nature of Men,' in Philosophy and Science in the Scottish Enlightenment, ed. P. Jones (Edinburgh, 1988), 145-168; G. W. Stocking, 'Scotland as a Model of Mankind: Lord Kames' Philosophical View of Civilisation,' in Towards a Science of Man: Essays in the History of Anthropology, ed. T. H. H. Thorensen (The Hague, 1975), 75-89; S. Sebastiani, 'Storia Universale e Teoria Stadiale negli Sketches of the History of Man di Lord Kames,' Studi Storici, 39:1 (1998), 113-136; S. Sebastiani, 'Razze, donne e progresso nell'Illuminismo Scozzese,' Passato e Presente, 50 (2000), 45-70; S. Sebastiani, 'Progress, National Characters, and Race in the Scottish Enlightenment,' Eighteenth-Century Scotland, 14 (2000), 11-15. On Kames's biography, see: W. C. Lehmann, Henry Home, Lord Kames, and the Scottish 
thesis in opposition to the universalistic assumptions which he saw in Ferguson's account of the development of civil society, criticizing in particular his parallel between the American tribes and the ancient Germans. ${ }^{20}$

Historians now rightly criticize Meek's account of the four stages theory as mere 'materialistic theory,' as he himself, in the 1970s, had criticized Dugald Stewart's definitions of it as mere 'conjectural history. ${ }^{21}$ Recent contributions, such as Mark Salber Phillips's Society and Sentiment, rightly highlight the complex novelty embedded in the historical approach of the Scottish Enlightenment: it was a narration of external as well as internal events, enlarging to sentiments, projects and designs, which encompassed both the 'male' genre in its search for truth and impartiality, and the 'female' genre in its quest to spark interest through sympathy. ${ }^{22}$ Christopher Berry has shown the 'sociological' dimension of the Scottish discourse and emphasised the wide range of subjects open to stage theory narrative and the character of 'natural history,' which was connected with the basic psychological assumptions

Enlightenment: A Study in National Character and the History of Ideas (The Hague, 1971); I. S. Ross, Lord Kames and the Scotland of his Day (Oxford, 1972).

20 A. Ferguson, An Essay on the History of Civil Society (1767), ed. by D. Forbes (Edinburgh, 1966), 80; Kames, Sketches of the History of Man, 1: 40-41, 44-45.

21 R. L. Meek, Social Science and Ignoble Savage, 231-243. For a critique of the definition of conjectural history as determinist and materialist, see A. S. Skinner, 'A Scottish Contribution to Marxist Sociology?', Classical and Marxian Political Economy, ed. I. Bradley and M. Howard (London, 1982), 104; D. Winch, Adam Smith's Politics (Cambridge, 1978); H. M. Höpfl, 'From Savage to Scotsman: Conjectural History in the Scottish Enlightenment,' Journal of British Studies, 7 (1978), 19-40; J. D. Brewer, 'Conjectural History, Sociology and Social Change in Eighteenth-Century Scotland: Adam Ferguson and the Division of Labour,' The Making of Scotland: Nation, Culture and Social Change, ed. D. Mc Crone, S. Kendrick, P. Straw (Edinburgh, 1989), 13-30. For the emphasis on natural jurisprudence, see K. Haakonssen, The Science of a Legislator (Cambridge, 1981), and Natural Law and Moral Philosophy: from Grotius to the Scottish Enlightenment (Cambridge, 1996). For an attempt to look 'backward' rather than 'forward' to set a proper context for Scottish conjectural history, see R. L. Emerson, 'Conjectural History and Scottish Philosophers,' Historical Papers: Communications historiques (1984), 63-90.

22 M. S. Phillips, Society and Sentiment: Genres of Historical Writing in Britain, 1740-1820 (Princeton, 2000); 'Reconsideration on History and Antiquarianism: Arnaldo Momigliano and the Historiography of Eighteenth-Century Britain,' Journal of the History of Ideas, 57:2 (1996), 297-316; “'If Mrs. Mure Be Not Sorry For the Poor King Charles": History, Novel, and The Sentimental Reader,' History Workshop Journal, 43 (1997), 110-131. 
of the theory itself. ${ }^{23}$ To my mind, whatever name or aspect we might choose to emphasise in re-describing 'four stages theory' — the jurisprudential paradigm, environmentalism, natural history, psychology, or the sentimental attitude - there is a feature common to all the major Scottish historians of the 1770s that their own contemporaries recognized as novel. The narratives in their histories ran autonomously, and notwithstanding formal claims of orthodoxy, without any help from God. To the editors of the successive editions of the Encyclopaedia Britannica these were histories of a world whose capital was the 'Castle of Scepticism': James Beattie's nightmare in which David Hume, the atheist, reigned. ${ }^{24}$

From its inception, the Encyclopaedia Britannica assumed a favourable position towards the Bible and orthodoxy. In his long article 'Abridgement' in Britannica's first edition, William Smellie used George Campbell's arguments to oppose Hume's criticism of miracles. ${ }^{25}$ His colleague James Tytler took the opportunity afforded by the article 'America' to address the new heterodox challenge in the Scottish philosophical debate, and defended the truth of the Mosaic account against Kames's polygenism. ${ }^{26}$ It was, however, the third edition that consistently set the Scriptures in opposition to the 'histories' of the Enlightenment. Under the guidance of the Episcopalian clergyman George Gleig, the celebrated philosophical unity of the Britannica on the subject of human history can

23 C. J. Berry, 'Rude Religion: The Psychology of Polytheism in the Scottish Enlightenment,' The Scottish Enlightenment: Essays in Reinterpretation, ed. P. Wood (Woodbridge, Suffolk, 2000), 315-334, quotation on 326; C. J. Berry, The Social Theory of the Scottish Enlightenment (Edinburgh, 1997).

24 E. C. Mossner, 'Beattie's "The Castle of Scepticism": An Unpublished Allegory against Hume, Voltaire and Hobbes,' University of Texas Studies in English, 27 (1948), 108-145.

25 'Abridgement,' EB1, 1: 6-7. Here Smellie asserts that 'in Dr Campbell's Dissertation on Miracles, the author's principal aim is to show the fallacy of Mr Hume's argument; which he has done most successfully.' Dealing with the rules and methods of making encyclopedias, 'Abridgement' is considered one of Smellie's most original and interesting entries in the EB1. See F. A. Kafker, 'Introduction' to Encyclopaedia Britannica, and 'William Smellie's Edition of the Encyclopaedia Britannica,' in 'Notable Encyclopaedias of the Late Eighteenth Century: Eleven Successors of the Encyclopédie,' ed. F. A. Kafker, Studies on Voltaire and the Eighteenth Century, 315 (1994), 145-254.

26 'America,' EB2, 1: 288-308. For analysis of this entry and its changes through Britannica's eighteenth-century editions, see S. Sebastiani, "The Changing Features of the Americans in the Eighteenth-Century Britannica,' in Across the Atlantic. Cultural Exchanges between Europe and the United States, ed. Luisa Passerini (Bruxelles, 2000), 39-57. 
be attributed to the reassertion of the Mosaic account. In addition to the more than 300 articles on theological subjects of which Gleig boasted, religious orthodoxy affected entries on natural history inserted in the second edition, such as 'Colour of human species' and 'Comparative anatomy. ${ }^{27}$ The third edition added the new article 'Savage,' whose approach to the problem of the progress of man was mirrored in the extended and significantly revised articles 'Society' and 'Moral philosophy.' The systematic defence of the Scriptures was completed by a network of cross-references to entries such as 'Babel,' 'Bible,' 'Chronology, ' 'Creation,' 'Miracle,' and 'Religion,' which were also linked to the historical-philological articles, written by the erudite philologist David Doig, a member of the Royal Society of Edinburgh and of the Society of Antiquaries of Scotland. ${ }^{28}$ This built-in polemic had two main targets: polygenism, and the theory of the universal and original savage state. The introductory observations of the article 'Society,' written for the most part by Robert Heron, ${ }^{29}$ sometime assistant of Dr. Blair, explained that these two ideas were intrinsically connected. Heron vigorously attacked 'those philosophers who have made society, in its various stages between rudeness and refinement, the subject of their speculations,' and who thought of mankind 'as proceeding uniformly through certain regular gradations from one extreme to the other. ${ }^{30}$ His conclu-

27 With the second edition the study of man was included in the sphere of 'natural history.' The editor Tytler sided with Dr. John Hunter in defence of monogenism, against those who thought that 'the whole human race have not sprung from one original' ('America,' EB2, 1: 288-308; 'Colour of human species', EB2, 3: 2083-2084). He also defended the uniqueness of the human being, asserting that, notwithstanding many physical similarities, the interval which separated man from orang-utan was immense ('Comparative Anatomy,' 3: 2146-2165; 'Simia,' 10: 8166-72). In this way, Britannica's second edition anticipated some of the main arguments of the third edition.

28 On the intellectual background of David Doig (1719-1800) and his links to neo-Hutchinsonian thought: P. Wood, 'Introduction,' in S. S. Smith \& D. Doig, An Essay on the Causes of Complexion and Figure in the Human Species \& Two Letters on the Savage State, Addressed to the Late Lord Kames (Bristol, 1995), v-xxv.

29 Robert Heron (1764-1807), polymath and member of the General Assembly of the Church of Scotland, contributed to many reviews and magazines, including the Edinburgh Magazine, the London Review, the Universal Magazine, the Anti-Jacobin Review, and wrote A New General History of Scotland, 5 vols., Perth, 1794-99. See 'Heron, Robert,' in T. Thomson, A Biographical Dictionary of Eminent Scotsmen (London, 1874-5), 2: 258-260.

30 'Society,' EB3, 17:568-90; quotation on 569. Although my interpretation is now deeply different, the first hint of this came from an interesting article by Pierangelo 
sions were extremely clear: 'They appear to consider the inhabitants of every different region of the globe as aborigines springing at first from the ground, or dropped on the spot which they inhabit,' in opposition to the orthodox reading of Genesis. ${ }^{31} \mathrm{He}$ further suggested that polygenism was immediately linked to the four stages theory, and was a direct consequence of its philosophical premises.

Thus the Encyclopaedia Britannica adopted the same critical approach expounded by David Doig in his Two Letters on the Savage State, written in 1774-75 but not published until $1792 .{ }^{32}$ These Letters were published, with an 'Advertisement' by George Gleig himself, at a time when the 'atheist' French philosophy was producing its deplorable fruit of French republicanism and emergent Jacobin dictatorship. When Doig originally wrote them, the Two Letters were an immediate reaction to the histories produced by the Enlightenment, of which Kames was considered a typical and celebrated Scottish representative. They were published now, wrote Gleig in the 'Advertisement', because it was more than ever necessary to defend the 'cause of Revelation. ${ }^{.33}$ Through a critique of Kames's Sketches, Doig intended to undermine the logical, philosophical and moral bases of the whole conjectural history, by denying its starting point: the existence of a primordial and universal savage state. To the mind of the erudite philologist, the stage theory emancipated man from God by asserting that he could progress by his own natural talents, propensities and qualities, without any other guide than his 'moral sense.' As Doig wrote, and the third edition of the Britannica echoed, the doctrine which presupposed men to be in a savage state at the beginning of the world directly descended from the ancient materialistic philosophers Epicurus and Democritus. The 'imaginary' idea that men could be borne from the earth, which Kames alone had the courage to support openly with his polygenetic speculations, should be recognised, however, as the implicit premise of every conjectural history. Thus, Doig linked the stage theory to Condil-

Castagneto, 'Uomo, natura e società nelle edizioni settecentesche dell'Encyclopaedia Britannica,' in 'L'enciclopedismo in Italia nel XVIII secolo,' ed. G. Abbattista, Studi Settecenteschi, 16 (1996), 435-476.

'Society,' EB3, 17: 569.

32 D. Doig, Two Letters on the Savage State, Addressed to the Late Lord Kaims [sic] (London, 1792). Doig transmitted and discussed with Kames himself the first of his two letters, dated 20 December 1774, while the second (12 March 1775), was never sent to the Scottish judge, being a reassertion and strengthening of Doig's previous arguments. See 'Advertisement,' $x$-xi.

G. Gleig, 'Advertisement,' Doig, Two letters on the Savage State, xiii. 
lac's sensism; to the eccentric ideas of Lord Monboddo, who put Horace's definition of the first men as 'mutum turpe pecus' in the epigraph of his Origin and Progress of Language; and finally to Rousseau. Adam Smith's Dissertation on the Origin of Languages, in which the professor of Moral Philosophy reconstructs the gradual formation of language while overlooking God's dealings with Adam, also came under attack. ${ }^{34}$ Some letters by his former student James Wodrow suggest reservations about Smith's orthodoxy as early as his lectures at Glasgow, where Smith inaugurated a new course in moral philosophy that was based on Hume's psychology rather than on the providential outlook of his predecessor Francis Hutcheson. ${ }^{35}$ What Doig and the third edition of the Encyclopaedia Britannica stressed was that Smith, Kames and Hume shared the assumptions of the French Enlightenment. ${ }^{36}$

The article 'Society' therefore asserted, following the Bible, that 'the first societies of men lived under the patriarchal form of government,' whereby the husband-father had absolute power over his family, and under which men employed themselves in the cultivation of the ground and in the management of the flocks and herds. This demonstrates clearly that 'though many of the rudest tribes are found in the state of hunters or fishers; yet the hunting and fishing state cannot have been invariably the primary form of society. ${ }^{37}$ In the new introduction to the article 'Moral Philosophy,' concerning the 'History of the Science of Morals,' Gleig coherently contrasted himself with both those philosophers who considered society as a consequence of benevolent human nature and those who, on the contrary, saw its origin in the instinct of self-preservation. ${ }^{38}$ The entries 'Savage,' 'Moral Philosophy,' and 'Religion' dismissed as 'a wild reverie' the idea that the first men were 'savages of the lowest rank. ${ }^{39}$ Adam was not a savage; though some 'modern

34 A. Smith, 'Considerations Concerning the First Formation of Languages' (1761), in The Works of Adam Smith, ed. D. Stewart, I (Otto Zeller, Aalen, 1811). In his Biographical Memoir, Dugald Stewart considered this text 'a very beautiful specimen of theoretical history' (Collected Works, 10: 37).

35 P. Wood, 'The Fittest Man in the Kingdom: Thomas Reid and the Glasgow Chair of Moral Philosophy,' Hume Studies, 23:2 (1997), 277-313.

36 Doig, Two Letters, 5-8.

37 'Society,' EB3, 17: 569.

38 'History of the Science of Morals,' in 'Moral Philosophy,' EB3, 12: 273-279.

39 'Religion,' EB3, 16: 60-77, quotation on 61. See also 'Savage,' EB3, 16: 672; 'Moral Philosophy,' EB3, 12: 272. 
philosophers' 'fancied' the idea, it was impossible that God would have abandoned his 'noblest creatures' at the moment of creation to wander the earth for ages without the use of speech, only gradually civilizing themselves. ${ }^{40}$ It was also an idea 'inconsistent with the phenomena of human nature,' since man is not provided with the instincts which unconsciously guide the other animals to their own preservation. ${ }^{41}$ Logic, reasoning and science, therefore, confirm the truth of the Old Testament. Indeed, the article 'History' notes that, since it is the only authentic and reliable source on ancient times, it would be 'impossible at this day to write a general history of the world' without it. ${ }^{42}$ The biblical account and the new histories based on the stage theory were clearly at odds:

When God had formed Adam and Eve, Moses does not say that he left them to acquire by slow degrees the use of their senses and reasoning powers, and to distinguish as they could fruits that were salutary from those that were poisonous. No: he placed them in a garden where every tree but one bore fruit for food; $[\ldots]$ he brought before them the various animals which roamed through the garden; he arranged these animals into their proper genera and species; and by teaching Adam to give them names, he communicated to the first pair the elements of language. ${ }^{43}$

The problem of the savage state was crucial, as Gleig saw it, because it affected the conception of man, his qualities, the powers of his mind, the criterion of virtue and 'the principle or motive by which men are induced to pursue it. ${ }^{44}$ In short, it was the central problem of human history and civil society. The new histories produced by the Enlightenment united in debasing man to the animal condition, only to raise him to a divine state,

'Religion,' EB3, 16: 61.

41 'Religion,' EB3, 16: 61; 'Instinct,' EB3, 9: 259-269.

42 'History,' EB3, 8: 561-600, quotation on 561. 'History,' which presents few differences from the article appeared in the second edition ('History,' EB2, 5: 3649-3688), devotes an entire section to 'Ecclesiastical History' and is entirely based on the traditional Biblical chronology. It is particularly interesting and a bit surprising that Adam Ferguson should be the author of the 'Historical Chart' attached to the end of this article starting with the second edition. Further research on this point would be interesting.

'Religion,' EB3, 16: 62. 
by attributing to human nature a natural propensity to improvement. The article 'Savage,' which faithfully rehearsed Doig's critique of Kames, confirmed this opposition to the idea of progress: 'man cannot, or, which is the same thing, has not risen from barbarism to civilization and science by his own efforts and natural talents. ${ }^{45}$ Otherwise, if we follow the principle asserted by Hume that 'natural causes operating in the same direction and with the same force, must in every age produce the same effects,' savage peoples would no longer exist. The principle of similar reactions to similar contexts, which was a crucial assumption of the stage theory, could thus itself be used to prove that human nature had no propensity to progress, but rather an inclination to remain static or else to degenerate, and by so using it, the editors of the Encyclopaedia Britannica showed, in the clearest possible way, the radically universalistic principle behind the idea of 'natural progress' in the stage theory. In one sense, the Britannica accepted Kames's reasoning on the varieties of development in men so that it could criticize the whole modern progressive framework of Scottish and European Enlightenment.

In the eyes of Gleig and Doig, the existence of savage societies constituted historical and social matter of fact. ${ }^{46}$ However, these societies were, from their Bible-centred point of view, the consequence of the Fall; after Adam was driven from the garden, some of his offspring 'degenerated' into savages. Both physical causes - such as differences in climate or

46 'Savage,' EB3, 16: 671; G. Gleig, 'Advertisement,' in D. Doig, Two Letters, viii-x, xii-xiii; D. Doig, Two Letters, 4 ff., 38-39. It is worth noting that this attack to the universal and primordial savage state also appears in the second edition of An Essay on the Causes of the Variety of Complexion and Figure in the Human Species, by another critic of Kames's Sketches of the History of Man, Samuel Stanhope Smith, professor of Moral Philosophy in Princeton. The first edition of this essay, published in Philadelphia and London in 1787 and then in Edinburgh in 1788, was already an important and broadly quoted source for Britannica's third edition. In 1810 Smith followed Doig in the assertion that 'the hypothesis that the human kind is divided into various species, radically different from one another, is commonly connected in the systems of philosophers with another opinion, which, however general the assent which it has obtained, is equally contrary to the true philosophy, and to the sacred history; I mean the primitive and absolute savagism of all the tribes of men.' See: S. S. Smith, D.D. L.L.D., An Essay on the Causes of the Variety of Complexion and Figure in the Human Species. To Which are Added, Animadversions on certain Remarks made on the first edition of this Essay, by Mr. Charles White, in a series of Discourses delivered before the Literary Society of Manchester in England. Also, Strictures on Lord Kaims' Discourse on the Original Diversity of Mankind. And An Appendix (Philadelphia, 1810), 15-16. For a recent reprint of the Edinburgh edition of Smith's Essay, edited by Samuel Smith Barton in 1788, see n. 28. 
region - and moral ones - human indolence, for instance - can easily explain how men, dispersed over the earth, might have degenerated, 'though descending all from the same original pair, and though enlightened with much traditionary knowledge relative to the art of life, the order of society, moral distinctions, and religious obligations. ${ }^{47}$ The article 'Society', therefore, although appearing to echo the account of the stadial progress, offers, instead, a complete confutation and an entirely alternative model. There are five stages between rudeness and civilization, Heron explains. The first is a savage state, where men live in a state of indifference, hunting and fishing, with great physical force but weak sentiments and minds. In the second, defined still as a savage state, men are united by a kind of government and have more highly developed morality, social virtues, and religious sentiments. Differences among the ranks of society appear only in the third stage, alongside the birth of property; duties multiply here, men become servants, masters, husbands and fathers, and the inequalities between the sexes increase. In the fourth stage agriculture flourishes and the progress of society advances quickly, thanks to the division of the several arts and the birth of commerce. At the fifth stage, finally, the arts, literature and sciences are cultivated; government is firmly established; the ferocity of barbarism disappears; the subordination of women becomes milder; social duties are strengthened; and religion becomes kind, humane and gentle. ${ }^{48}$ The appearance of luxury in this stage is a decisive agent of the civilization of society, encouraging commerce and social intercourse. This is, in fact, the period when human virtue and human abilities shine with the greatest splendour. Nonetheless, beneficial luxury, the best friend of society at the beginning, becomes its worst enemy and the main cause of its degeneration following this golden age. Human history records recurrent periods of decadence: to the ancient Assyrians, Egyptians, Greeks, Romans, and Arabs, Heron adds the modern Portuguese, Venetians, Spanish, and now even revolutionary France.

Ferguson and Kames also denounced the dangers of luxury, emphasizing the risks of decadence for commercial societies, and Smith and Millar had their reservations about some of the consequences of contemporary development, especially regarding the conditions of the working

48 This is in contrast to what happens in ruder stages, where religion is often cruel and bloody. In the entry 'Polytheism,' Gleig explains the way in which peoples can degenerate from the belief in the true God to that in a multitude of false divinities (EB3, 15: 336-349). 
classes. ${ }^{49}$ It is not my aim here, however, to show that the historians of Scottish Enlightenment did not envision an inevitable catastrophic end to society, despite all of their doubts. For my purposes, it is also secondary that in the article 'Society' there appears no distinction between the savage and the shepherd states, which actually are demarcated by the longest and most difficult step in the four stages theory - the development of property. ${ }^{50}$ What is critical, instead, is that the conceptual bases of the analyses are completely different. Consistent with what has already been said, the progressive path indicated by Heron follows the fall into the savage state: only some peoples became savages, while others preserved their original knowledge and proceeded from there.

The article 'Society' thus followed the Bible, even when it conceded the existence of a certain stadial progress: Adam and Eve fed on fruits, Cain and Abel were shepherds and farmers, then towns were formed and arts had been diversified. After the Flood, the patriarchal families descended from Noah became tribes who repopulated the earth, once more developing the arts and commerce and the luxury and corruption associated with it. ${ }^{51}$ This brings us to Grotius's classic discussion of the origins of property in De iure belli ac pacis, where there is no contradiction between sacred and profane history. ${ }^{52}$ The distance from Britannica's account and that of the Scottish Enlightenment is plainly explained by Heron himself: 'It is indeed impossible to exhibit under one general view an account of arts, manners, and religious sentiments, which may apply to some certain period in the history of every nation. The characters and

49 On this much debated issue, see for example D. Forbes, 'Introduction,' A. Ferguson, An Essay on the History of Civil Society (Edinburgh, 1966), xiii-xli; R. L. Heilbroner, "The Paradox of Progress: Decline and Decay in The Wealth of Nations,' in Essays on Adam Smith, ed. A. Skinner and T. Wilson (Oxford, 1975), 524-39; M. Jack, Corruption and Progress: The Eighteenth-Century Debate (New York, 1989); D. Spadafora, The Idea of Progress in Eighteenth-Century Britain (New Haven, London, 1990); R. B. Sher,'From Troglodytes to Americans: Montesquieu and the Scottish Enlightenment on Liberty, Virtue, and Commerce,' in Republicanism, Liberty and Commercial Society 1649-1776, ed. D. Wootton (Stanford, 1994), 378-402; C. J. Berry, The Idea of Luxury: A Conceptual and Historical Investigation (Cambridge, 1994).

50 A. Smith, Lectures on Jurisprudence, ed. R. L. Meek, D. D. Raphael, P. G. Stein (Oxford, 1978), 107. Report of 1762-63, ii: 99.

51 R. L. Emerson argues the importance of Biblical sources of the four stages theory in 'Conjectural History and Scottish Philosophers,' Historical Papers: Communications historiques (1984), 63-90.

52 H. Grotius, De iure belli ac pacis (1625), English trans. by F. W. Kesley, The Law of War and Peace (Washington, 1964), 186-190. 
circumstances of nations are scarce less various and anomalous than those of individuals. ${ }^{53}$ Thus, the stages which the Encyclopaedia Britannica wrote about did not form a typology such as the one used by the Scottish Enlightenment historians, one on which a reliable account of progress can be founded.

According to the editors of the Britannica, the progress of society is not a natural process, but the work of God. Though the distance between Adam Smith's 'invisible hand' and the visible work of Providence could be considered small, the author of The Wealth of Nations did not cross the line: as James Wodrow would write in 1808 , Smith saw the history of men as if their minds and powers were shaped by circumstances and stages of society, not by the hand of the creator. ${ }^{54}$ To the editors of the Britannica, however, progress was the result of the direct intervention of God. This is a crucial difference even from those who, like Dugald Stewart or William Robertson, could claim that human history realised the ends of Providence. Progress is, in fact, for Doig, Gleig and Heron due to 'some persons endowed with superior talents, or in the language of poetry, some heroes, semi-gods, or god-like man,' sent by God to civilize men. They are the mythic legislators, who having apprehended knowledge from more civilized nations 'sowed the first seeds of civilization among the hordes of wandering disunited barbarians. ${ }^{, 55}$ They never lost the knowledge given by God to Adam; they were raised from the Fall by a direct act of the Creator, the Revelation being given only to 'some chosen individuals commissioned to instruct others. ${ }^{56}$ In the Britannica, history does not move without miracles, and left to itself humankind does not progress; rather, it degenerates. Further, history clearly demonstrates that 'man, once a savage, would never have raised himself from that hopeless state.' So,'had all mankind been once in the savage state, they never could have arrived at any considerable degree of civilization. ${ }^{57}$ For Doig, Gleig and Heron, therefore, humankind and civilization spread from the Middle East to the rest of the world according to what has been defined as an 'eliodromic' theory of the diffusion of mankind and culture. As the Greeks would have not have developed

54 James Wodrow to Samuel Kenrick, 5th July 1808, Dr William's Library, MS 24.157 (263) ii, quoted in P. Wood, 'The Fittest Man in the Kingdom,' 288.

'Savage,' EB3, 16: 672-3; D. Doig, Two Letters, 64-68.

'Miracle,' EB3, 12: 169-174, quotation on 70. This article was written by George Gleig. 
beyond their original barbarism without the influence of the Egyptians, and the Italians would not have advanced without Greek knowledge, so the American Indians would have been destined to remain in their savage state without the intervention of the Europeans. As Gleig puts it in his biography of Principal William Robertson, the Spaniards had the same role in America as the Romans had had in Europe, bringing literature and science and preparing peoples for the reception of 'true religion.' Here, Gleig's argument reversed Dugald Stewart's review of the History of America, which criticised Robertson's inclination to veil the cruelties of the Spanish conquest, relying on De Pauw's and Buffon's prejudices. Instead, wrote the editor of the third edition of the Britannica, in the future 'Cortes will, like Caesar, be considered merely as an instrument employed by Providence to forward its inscrutable purposes. ${ }^{, 58}$ Thus, the stages of the article 'Society' did not actually describe the history of progress, but rather offered a revised account of traditional Christian euro-centric assumptions. The Western settlers were the modern, semi-divine legislators, sent by God into the 'uncivilized' parts of the globe.

Contrary to the innovative conceptions of man and the history of mankind propounded by late eighteenth-century enlightened culture, the editors of the Encyclopaedia Britannica's third edition reaffirmed their fidelity to the Mosaic account. The historical providential framework found in the Scriptures was defended and confirmed in the articles on philosophy, history, and religion, which were primarily written by Gleig. Physical anthropology and comparative anatomy, once incorporated into the Britannica, permitted the reaffirmation of the idea of the superiority of man compared to nature's other creatures. At the same time, these articles affirmed the uniqueness of mankind across climates, also in the fields of the new natural sciences, giving more strength to Buffon's monogenetic position. ${ }^{59}$

58 G. Gleig, Some account of the Life and Writings of William Robertson, D.D.F.R.S.E., Late Principal of the College of Edinburgh, and Historiographer to His Majesty for Scotland (Edinburgh, 1812), lvi; contrast D. Stewart, Biographical Memoirs, 241-242.

59 The increasing importance of the scientific approach in the EB3 is attested by the numerous references to the researches of Johannn Friedrich Blumenbach and Eberhardt August von Zimmermann; Thomas Jefferson, Samuel Smith Barton, and Samuel Stanhope Smith became other important sources. See, for instance: 'America,' EB3, 1: 537-617; 'Comparative Anatomy,' EB3, 5: 249-274; 'Complexion,' EB3, 5: 286-90; 'Negroe,' EB3, 12: 794-798; 'Slavery,' EB3, 17: 522-534; 'Man,' Supplement to the Third Edition of the Encyclopaedia Britannica [...]. In two volumes, by George Gleig, 2nd ed. with improvements (Edinburgh: Thomson Bonar, 1803), 2: 164-165. 
The entries 'Mysteries,' 'Mythology,' 'Philology,' written by David Doig, who, like Gleig came from Stirling, made it possible to see this historical and scientific position in a context which strongly reasserted the Christian Revelation and its 'superiority,' thanks to the comparison with the other religious traditions. The critique of the savage state and polygenesis, which gave birth to his Letters in opposition to Kames, laid the foundation of the historical ideology of the third edition of the Encyclopaedia Britannica. There, both the French and Scottish Enlightenments were regarded as unique dangers to religion and society. In incorporating Doig's critique, the editors of the Britannica thus did not seem to recognise the differences between Rousseau's idea of human perfectibility, sensism, and the Scottish sociological approach. As I have emphasised, this type of critique was not a simple by-product of British horror regarding the events of the French Revolution. It was instead recorded at the very moment that conjectural history was devised and adopted as the standard framework for the historical enquiry of the Scottish Enlightenment. Doig and Wodrow are clear examples of this early reaction. Before the 1790 s, these critiques were only private utterances that remained unpublished and almost unheard. The events of the French Revolution, however, rendered this kind of analysis acceptable as an alternative to Scottish historiography and its idea of progress. The approach of Smith, Ferguson, Millar and Kames was not materialistic in itself, but to a staunchly conservative point of view their analysis was materialistic in tendency, and antagonistic to the Mosaic account. In these terms, Britannica's editors exactly identified what makes the Scottish historians part of the European Enlightenment, a diversified movement with one common denominator: the secularisation of society and the history of mankind. Doig wrote in the 1770s and the Encyclopaedia Britannica reiterated in the 1790s that in the Christian world there is no room for the primordial and universal savage state. The conception of man's progress towards civilization as natural, of human history without the hand of God, was thus under attack.

SILVIA SEBASTIANI

European University Institute 